\title{
Michal SKŘEJPEK
}

Law Faculty, Charles University in Prague

\section{THE CONCEPT OF ‘THINGS' AND THEIR DEFINITION IN THE NEW CZECH CIVIL CODE FROM THE PERSPECTIVE OF ROMAN LAW}

The new Czech Civil Code was passed in 2011 and became effective on 1 January 2014. It should be noted that the date when the Code was to come into effect was not settled until late autumn 2013. The Czech Parliament had been expected to pass about fifty other laws intended to harmonize all parts of private law with the new Civil Code, in particular employment law and commercial law, which have been substantially affected by the Code. Harmonization was intended not only to bring conformity to the content of individual laws but also to uniformly apply terminology introduced by the Civil Code. Significant shifts in naming certain contracts in the Czech equivalent to the Latin terms mutuum and commodatum may illustrate the process. Other examples include the introduction of new, and re-introduction of some former institutions, such as gratuitous loan (precarium); prudent manager; self-redress applicable not only to cases of self-defence but also as a tool of enforcement of one's rights ${ }^{1}$; or the invalidation of juridical acts which are contrary to good morals.

The drafters of the new Czech Civil Code declare that the resources for their legislative work were the Austrian General Civil Code of 1811 ("AGBG") and the Government Draft of a statutory act which should

\footnotetext{
1 See Section 14. Self-redress is limited only by two factors: (a) the agent's subjective belief that any intervention by a public body would be late, and (b) the duty to address the public body immediately after the application of self-redress.
} 
have become the Civil Code No. 844 of 1937 ("1937 Government Bill"). The latter has been designated in sec. 17 of the Explanatory Report on the new Czech Civil Code as the primary ideational basis of the recodification. The 1937 Government Bill was an outcome of long-lasting attempts to create a new codification of Czechoslovak civil law in the two decades between the World Wars and dating back to the origins of independent Czechoslovakia in 1918. The unification of civil law at that time was urgently required as there had been two jurisdictions in operation on the territory of Czechoslovakia, one resulting from Austrian law and based upon ABGB (in the Czech territories), the other following Hungarian law (in Slovakia). However, those attempts did not lead to a positive and successful end due to many reasons. Obstacles were partly produced by the political situation of that time, as legislative work was halted as a result of the Munich Agreement; other reasons were substantive, as the drafting of a final version of provisions for obligations in the Bill was delayed by a pending recodification of business law. The Austrian ABGB remained in force in the Czechoslovak Republic until 1950, when it was replaced by a new Civil Code drafted within the so-called "two-year plan for law" pursued after the Communists took over the government of the country. The next code - the Civil Code of 1964 - was effective, with many substantial amendments, until 31 December 2013.

Many links to Roman law can be traced in the text of the new Czech Civil Code itself. The drafters of the Code refer to Roman law in various parts of the Code Explanatory Report. The part entitled "Main principles" contains an explicit comment as follows: "European legal culture is built upon Roman law; its institutions particularly in the area of property rights have a decisive impact on modern civil codes" (p.18). References to individual institutions and legal principles stemming from Roman law can be found throughout the whole Explanatory Report. Examples are a uniform concept of ownership without distinguishing between an "owner" (vlastnik) and "proprietor" (majitel) (p. 245); animus revertendi (p. 256); the superficiary right of building on the land of another (p. 308); laesio enormis (lesion beyond moiety, p. 421); offset (p. 442); the regulation of unjust enrichment (p. 554). 
Let us attempt to verify the drafters' declaration, specifically that they considered Roman law to be a decisive factor for the drafting of modern civil codes, by analysing the simple and apparently noncomplex issue of the classification of things and its characteristics. As noted earlier, the drafters intentionally follow older legal regulations. Therefore, a comparison of relevant provisions of the new Czech Civil Code with corresponding clauses in the ABGB and the 1937 Government Bill may serve our purpose. It should be added that many parts of the wording of the respective sections of the 1937 Government Bill have been carried over and included in the new Czech Code without any changes.

The issue under consideration is contained in Title Four, Chapter 1, entitled "Things and their division" (ss. 489-544). Compared to other codes of civil law which have applied on our territory, this passage is rather extensive: there are only 25 sections providing for this issue in the ABGB (ss. 285-308); 7 sections in the Civil Code of 1950 (ss. 23-29); and only 4 sections in the Civil Code of 1964 (ss. 118-121). What may be very interesting is a comparison with the Government Bill of 1937, where the division of things is stipulated in 18 sections (ss. 80-98).

The elementary issue is the definition of the concept of a thing. The Explanatory Report on the 1937 Government Bill states (p. 257) that a preparatory committee dealing with that part of the Bill suggested giving up any attempts to formulate a definition of a thing, i.e. to omit the provision of s. $285 \mathrm{ABGB}$, and leaving that task to jurisprudence. Such a proposition was based on the rational premise that the multifarious nature of economic life was continually creating new institutions which are in their essence of the nature of things; as a result it seemed impossible to create a definition that would be predictive to a certain extent. Members of this early $20^{\text {th }}$-century committee remained quite exceptionally immune to an illusion which has attacked all codifiers, namely that they would be able to formulate a perfect and definitely valid norm without any gaps. Needless to add, the Roman lawyer Iavolenus said hundreds of years ago: "Omnis definitio in iure civili periculosa est: parum est enim, ut non subverti posset" (D. 50,17,202; 
Every definition in civil law is dangerous as only rarely will it never be irrefutable). Eventually, the final version of the 1937 Government Bill included section 80, containing the definition. What is interesting, and seems to be typical of the new Civil Code, the definition stipulated in its s. 489 is not only a literal copy of s. 80 of the 1937 Government Bill but also of s. $285 \mathrm{ABGB}^{2}$ : "A thing in the legal sense is every thing which differs from the person and serves for the use of people". What is not a thing under the new Civil Code? Live animals endowed with senses (s. 494). Logically, people are not things, or in the language of the new code "the human body and its parts whether separated or not" (s. 493). However, there is a hitch in this unequivocal provision fully corresponding with the Roman law concept, since one provision in Title Two, Division 6, entitled "Personality of an individual", of the new Code reads: "An individual may pass a part of his or her body to another only under conditions stipulated by another law. This is inapplicable to hair and similar parts of a human body that may be removed without any pain and anaesthesia, and are naturally renewable; such parts may be transmitted for value and are considered as a movable thing" (s. 112). What do the drafters specifically mean by this provision? Besides the hair on an individual's head there may also be nails and hair covering some parts of a human body. The sense of this provision is rather unclear; it will be a task for courts to reach a uniform interpretation of the provision.

The division of things, or of different types of things, dealt with by the new Civil Code is our main concern here. The first distinction is made between tangible (corporeal) and intangible (incorporeal) things ${ }^{3}$. Tangible things are defined as "manageable parts of the outer

2 English translation of individual provisions of ABGB referred to in this paper are taken from the General Civil Code for all the German Hereditary Provinces of the Austrian Monarchy. Translated by Joseph m. Chevalier de Winiwarter, Doctor in Law, Advocate in Vienna, and Legal Adviser to Her Britannic Majesty, Embassy at Vienna. Vienna 1866. Sold by Rudolph Lechner, Bookseller to the University.

3 Cf. s. 292 ABGB: "Corporeal things are those which strike the senses; in the contrary case they are called incorporeal, e.g. the right of shooting, fishing and all other rights." 
world having the nature of autonomous objects" (s. 496(1)). The same nature is assigned to tradable natural forces (s. 497). Comparing this definition with the wording of the 1937 Government Bill (s. 82), it is clear that the drafters of the new Czech Code took it over almost to the letter. Intangible things are defined as rights and things without corporeal substance (s. 496 (2)). Both definitions are in conformity with the concept of things in Roman law, as can be found in the Institutes of Justinian (2,2), in Gaius (2,12-14), and the Digests (Gai. D. $1,8,1,1)$.

The distinction between movable and immovable things as determined in the new Code appears to be the most controversial. Subsection 498 (2) states that all things which are not immovable are movable. Such a definition implies that res incorporales are in fact movables by their nature. The drafters of the Czech Code prefer the concept in ABGB, which reads (s. 298): "Rights are regarded as movable things if they are not connected with the possession of an immovable thing". The 1937 Government Bill, which served as a firm drafting basis for the drafters of the new Code, contains a slightly different wording in its s. 83 - "other things are movable"; however, the Bill considers rights linked to immovable things as immovables ${ }^{4}$. This concept is obviously a reflection of the Pandects, or post-Pandects, and the division of things in them, rather than in Roman law. This is not an exception in the whole context of the Code; rather it seems to be the usual practice.

Other types of the division of things are more or less in compliance with the concept in Roman law. There are fungible things, where every thing may be freely interchangeable with another of the same kind (s. 499) ${ }^{5}$, and consumable things (s. 500). The latter are defined as "movable things whose regular usage consists in their consumption, processing and alienation"6. Significant derogation from the "classical" concept of consumable things can be seen here. This concept defines

\footnotetext{
4 The Explanatory Report, p. 257.

5 See s. 93 of the 1937 Government Bill.

6 Neither the 1937 Government Bill nor ABGB include "alienation".
} 
consumables according to their physical features, whilst the new Czech Code combines their physical substance with their purpose as tradable goods. Simplistically understood, consumables under the new Czech Civil Code can include, for example, furniture or dishware.

In this context, the subject-matters of contracts covered by "real contracts" in Roman law should be mentioned here since real contracts as such are absent in the new Czech Code. An exception to real contracts under Roman law is pignus (a pledge for the benefit of both parties): the new Czech Code defines it in such a derogatory way that one can hardly find its basis in Roman law. In addition, the new Czech Code does not use the term "individually or generically determined things or performance" as applied in the preceding Civil Code of 1964. These words can only be found in the Explanatory Report (p. 439) in the passage dealing with section 1851 included in the part entitled "Obligations arising from contracts concluded by consumers", which is of a purely general nature. It is stated that only an agreement between parties is relevant to the determination of the performance which is to become the subject-matter of their obligations; if a thing is to be generically determined the performance should be a thing with regular qualities, which corresponds with the regulation in Roman law.

The subject-matter of mutuum (simple loan) may only be fungible things (s. 2390), i.e. things of the same generic description. Commodatum (loan for use) applies to non-consumables (s. 2193). Provisions governing a contract of deposit (or safekeeping contract) speak only of things (s. 2402) without specifying the subject-matter of such a contract; as a result, it may apply to all kinds of things movable or immovable, fungible or non-fungible, consumable or non-consumable. As can be seen, only the Czech regulation of mutuum corresponds to that of Roman law; the other two contracts are not in conformity with the Roman institutions and are regulated in a different manner.

Kinds of things are mentioned in connection with the right of usufruct (s. 1294); the institution of Roman law quasi ususfructus can be observed here. Where such rights are created with respect to consumable fungible things the new Czech Code reads: "If the right of 
use or enjoyment has been created with regard to consumable fungible things a person using or enjoying such things may dispose of them at his full discretion. When his right expires the person is to return the same amount of things of the same kind and quality".

The new Czech Code regulates the institution of a collective thing as follows: "A set of individual things belonging to the same person, considered as one object and as such designated by a common name, is treated as a whole and constitutes a collective thing" (s. 501). If this definition is compared with ABGB (s. 302) and the 1937 Government Bill (s. 91) one more element may be observed in the Czech provision, namely that the set of things must belong to one person.

A relatively detailed regulation in the Code covers component parts (appurtenances) and accessories of things (Chapter 3, ss. 505-513). The return of the new Czech Code to the values and principles of Roman law is most apparent in this Chapter. Several indications can be found in the regulation on component parts. First, it can be seen in the definition itself, which does not need any further comment: "A component part of a thing is what belongs to the thing by its nature and cannot be separated from the thing without destroying it" (s. 505).

The drafters of the Code not only declare ${ }^{7}$ their return to the principle of superficies solo cedit but also apply it. As a result a structure is considered a component part of land, unless it is a temporary construction. Relevant provisions are in s. 506, which deserves full quotation here, as it reflects the spirit of Roman law: "A component part of land is the space above and under the surface of the land, structures built on the land and other installations (hereinafter referred to as "structure") with an exception of temporary constructions, but including what has been embedded in the land and fixed to the walls".

The principle that "the surface yields to the ground" can be traced in two other passages in the new Civil Code relating to land and structures built upon it. The full formulation of Roman law is adopted and followed in sections 1083 and 1084 respectively: "Where a person uses another's materials to erect a structure on that person's land, the

7 The Explanatory Report p. 121. 
structure becomes a component part of the land". and "A structure erected on another's land belongs to the owner of that land".

The same principle can be found in the regulation on plants: "Plants planted on land form a component part of the land" (s. 507). ${ }^{8}$ This provision is linked to s. 1067 , which reads: "A tree belongs to the owner of the land on which the trunk of the tree grows". Finally, s. 1088 reads: "The owner of land acquires the ownership of what has accrued to that land as a result of sowing another's seeds or planting another's plants; however the plants become his property after they have taken root". It should be concluded that all these sections are typical, even copybook, examples of the reception of Roman law.

Another issue which deserves attention is the institution of accessions. S. 510 defines it as a thing accessory to the principal thing belonging to an owner. A requirement is stipulated that an accessory thing must be permanently used along with the principal thing in line with the economic purpose of both things. The accessory nature of a thing is persistent even if it has been separated from the principal thing. Juridical acts, rights and duties applicable to the principal thing also apply to accessions. This determination of accessions is emphasized in the Explanatory Report (p. 125): "Unlike accessions representing autonomous and autonomously tradable things whose purpose is to be used along with the principal thing, a component part is not an autonomous object of rights". The legal principle of accessorium sequitur principale has been preserved. This principle was contained in the 1950 Civil Code; however, it disappeared from the 1964 Civil Code. It should be noted that the application of the principle superficies solo cedit is one of the most significant Roman law features of the new Czech Civil Code.

Mention should be made of the systemization of Title IV of the new Czech Code dealing with things and their division. The definition of the concept of a thing and features of the division of things are followed by provisions determining the concept of a business establishment and its branches (ss. 502-503) and trade secret (s. 504). Chapter 4 of this Title

8 Cf. I. $2,1,31$. 
is devoted to securities. As a result, Title IV is quite heterogeneous if the substance and scope of individual provisions are considered. As similar heterogeneity can be traced in many other segments of the Code, it appears to be its common feature.

One significant defect of the new Code should be addressed, as all users of the Code - both lawyers and non-lawyers - will face it and have to cope with it. The defect lies in the new, or rather newly restored old terminology of the Code, including archaisms such as the Czech výmének (reserved right of usufruct). The new Civil Code conceals one more danger, namely that the knowledge of Roman law need not be a reliable aid in understanding the Czech Code although its drafters claim they used Roman law as a basic source. On the one hand, there are many pure Roman institutions such as actio aquae pluvie arcendae ${ }^{9}$, or societas leonina ${ }^{10}$. A typical example is the concept of servitudes. They are regulated in a manner typical of Roman law, i.e. in a casuistic way; there are servitudes such as the right to have rainwater conveyed from a neighbour's roof, the right of paths, the right to drive cattle and other animals over the servient land, the right of way, and the right of pasture $^{11}$.

On the other hand, many provisions just look like Roman law. A typical example may be the construction of acquisitive prescription and its conditions. All the conditions required by Roman law, namely possessio, titulus, bona fides, tempus, are present; however, one important requirement is missing - res habilis. As a result it may be possible to acquire by prescription the right of ownership of a stolen thing. The second example may be quarta Falcidia, which is formulated in s. 1598 in a clumsy manner. The section reads: "Each heir must receive at least one quarter of the value of inheritance free

9 "Where water inflow is needed in a plot located on a lower place its owner may request the owner of a neighbouring upper plot that he refrain from obstructing water from flowing down to the lower plot in a volume the upper plot owner may dispense with." (s. 1019 (2)).

10 "Provisions excluding the right of a member to his share of profit have no legal effect."(s. 2728 (2)).

11 Ss. 1271, 1272, 1274, 1276. 
of any legacy. Should the testator burden an heir more, the heir has a right to proportional reduction of the legacy". This formulation does not make much sense; instead of "at least one quarter of the value of inheritance", it should read "at least one quarter of the value of his inheritance share".

The drafters of the new Code were aware of some problems. At the very beginning of the Code (rules of interpretation) section 10 stipulates: "Where a legal case cannot be determined according to an express provision, the case is to be determined under the closest provision applicable to the case as to its content and scope. Should there be no such provision, the case is to be determined in compliance with equity and the principles upon which the Code has been constructed". Habits pertaining to private life should be taken into consideration, as well as established case law and legal doctrine. However, there may be a significant problem, as judges have estimated it may take as long as 20 years for established case law relating to the new Civil Code to be developed. Moreover, legal doctrine has been quite reserved with respect to the new Code and may be even perceived as meagre, as individual legal scholars have different approaches and opinions. In the light of this situation, the interpretation rules contained in the law of citations of Theodosius II and Valentinian III of 426 A.D. appear to be far more insightful if compared to s. 10 of the new Code. Both legal practice and case law will undoubtedly show how useful the new Civil Code will prove to be, not only in the field of things and their division, but also as a full text of law.

KONCEPCJA RZECZY I ICH DEFINICJA W NOWYM CZESKIM KODEKSIE CYWILNYM Z PERSPEKTYWY PRAWA RZYMSKIEGO

\section{Streszczenie}

W artykule podjęto próbę analizy regulacji nowego czeskiego Kodeksu Cywilnego, dotyczących zagadnienia podziałów rzeczy, w odniesieniu do ogólnej deklaracji ustawodawcy, który uznał, 
że „europejska kultura prawna jest oparta na prawie rzymskim, a jego instytucje, szczególnie w dziedzinie prawa rzeczowego mają decydujący wpływ na współczesne kodeksy cywilne”. Wiele przepisów odpowiada dokładnie rzymskim wzorcom, są jednak i takie, które - mimo pozornych zbieżności - odchodzą od prawa rzymskiego w istotnych szczegółach, pomijając jakąś przesłankę (np. przesłanka res habilis przy zasiedzeniu), co może prowadzić do trudności w ich zastosowaniu.

Keywords: New Czech Civil Code, division of things.

Słowa kluczowe: Nowy Czeski Kodeks Cywilny, podział rzeczy. 